\title{
Graft Copolymerization of Methyl Methacrylate and Vinyltriethoxysilane onto Natural Rubber
}

Phản ứng đồng trùng hợp ghép metyl metacrylat và vinyltriethoxysilane lên cao su thiên nhiên

\author{
Nghiem Thi Thuong*, Dao Van Huong \\ School of Chemical Engineering, Hanoi University of Science and Technology, Hanoi, Vietnam \\ Email: thuong.nghiemthi@hust.edu.vn
}

\begin{abstract}
Preparation and characterization of natural rubber grafted with methyl methacrylate (MMA) and vinytriethoxysilane (VTES) were performed in the present work. Graft copolymerization of methyl methacryate was carried out in latex stage, and VTES was added during the graft copolymerization of MMA. FTIR and NMR spectroscopy were used to investigate the structure of graft copolymer and determination of conversion and grafting efficiency of MMA. It confirmed that the poly(methyl methacrylate) (PMMA) and silica particles (PVTES) were successfully formed in NR-graft-PMMA-PVTES graft copolymer. Conversions of MMA were about 90-100\%; however, MMA grafting efficiency decreased as the MMA concentrations increased. Tensile property of NR-graft-PMMA-PVTES was found to improve compared with that of pure NR.
\end{abstract}

Keywords: Natural rubber, methyl methacrylate, vinyltriethoxysilane, graft copolymerization, tensile property.

Tóm tắt

Trong nghiên cứu này, quá trình tổng hợp và đặc trưng cao su ghép với metyl metacrylat (MMA) và vinyltriethoxysilane (VTES) được tiến hành. Quá trình đồng trùng hợp của metyl metacrylate được tiến hành ở trạng thái latex sau đó thêm vinyltriethoxysilanes vào trong quá trình ghép của MMA. Phổ hồng ngoại và phổ cộng hưởng từ hạt nhận được sử dụng để phân tích cấu trúc của cao su ghép và định lượng hiệu suất chuyển hóa và hiệu suất ghép của $M M A$. Kết quả cho thấy, poly(methyl methacrylate) $(P M M A)$ và hạt silica (PVTES) được tạo ra trong cao su ghép NR-graft-PMMA-PVTES. Hiệu suất chuyển hóa của MMA đạt khoảng 90-100\% trong khi đó hiệu suất ghép của MMA không cao, và giảm khi tăng nồng độ của MMA. Độ bền kéo của cao su ghép NR-graft-PMMA-PVTES, ví dụ là độ bền kéo đưt, được cải thiện so với cao su thiên nhiên chưa biến tính.

Từ khóa: Cao su thiên nhiên, metyl metacrylat, vinyltriethoxysilane, phản ứng đồng trùng hợp ghép, độ bền kéo.

\section{Introduction}

Natural rubber, harvested from Hevea Brasiliensis, is a natural polymer that comprises a long sequence of more than 5000 units of cis-1,4-isoprene linking with non-rubber components, such as proteins and fatty acids at two terminals. Because of this molecular characteristic, NR possesses exceptional intrinsic elasticity and mechanical properties compared to other synthetic polymers containing poly(cis-1,4-isoprene). However, due to $\mathrm{C}=\mathrm{C}$ bonds in the main chain, NR has its limitation in applications in the un-crosslinked state. Thus, NR is subjected to compound with various reinforcing fillers such as carbon black [1], silica [2], carbon nanotubes [3], nano-clay [4], nano-diamond [5], and so forth to increase its durability. Methods of incorporating the fillers were primarily achieved by latex or solid mixing. However, both methods are faced with poor dispersion of the fillers. The poor dispersion of silica could be solved by in-situ formations of silica by the sol-gel process. The colloidal silica particles have a good reinforcement for NR.

Besides compounding methods, various addedvalued NR-based materials could be prepared by chemical modification of NR. Among diverse chemical modification approaches, graft copolymerization is a versatile method to chemically modify natural rubber in which a vinyl monomer was grafted onto NR. The graft copolymerization combines properties of natural rubber as an excellent elastomer and functional groups of vinyl monomer. In previous works, various monomers such as styrene [6], methyl methacrylate (MMA) [7], vinyltriethoxysilane (VTES) [8], and MMA-styrene [9] were grafted on NR. It showed a remarkable enhancement in NR performances such as hardness, modulus, and thermal properties.

ISSN: 2734-9381

https://doi.org/10.51316/jst.153.etsd.2021.31.4.10

Received: November 19, 2020; accepted: April 2, 2021 
In our previous work [10,11], styrene and VTES were graft copolymerized onto NR. The enhancement in properties of resulting materials is due to the chemical linkages between NR and organic functional polymer and the formation of silica by sol-gel reaction with better dispersion. Thus, the combination of graft copolymerization and sol-gel reaction in one batch will benefit from forming good dispersion of filler and chemical linkages between the filler, the polymer, and NR particles.

In the present work, we performed graft copolymerization of MMA and VTES onto natural rubber latex after removing of proteins. At first, graft copolymerization of MMA was proceeded to form graft copolymer NR-graft-PMMA, and after that, VTES was added during the graft copolymerization. The structure of graft copolymers was carefully analyzed. The effect of MMA on VTES conversion and the effect of VTES on MMA grafting efficiency was discussed. The colloidal silica was proved to form in the graft copolymer. The role of colloidal silica and PMMA on tensile property of NR was also investigated.

\section{Experiment}

\subsection{Materials}

Natural rubber latex (HANR), preserved with high ammonia, was kindly provided by Dau-Tieng rubber company with dried rubber content (DRC) of 63 wt.\%. Methyl methacrylate, vinyltriethoxysilane, tert-butyl hydroperoxide (TBHP), and tetraethylenepentamine (TEPA) were brought from Tokyo Chemical Industry (Japan). Surfactant sodium dodecyl sulfate (SDS, 99\%) was provided by Kao chemicals company (Taiwan). Urea (99.5\%) was purchased from Merck (Germany). The other chemicals were analytically graded.

\subsection{Graft copolymerization procedure}

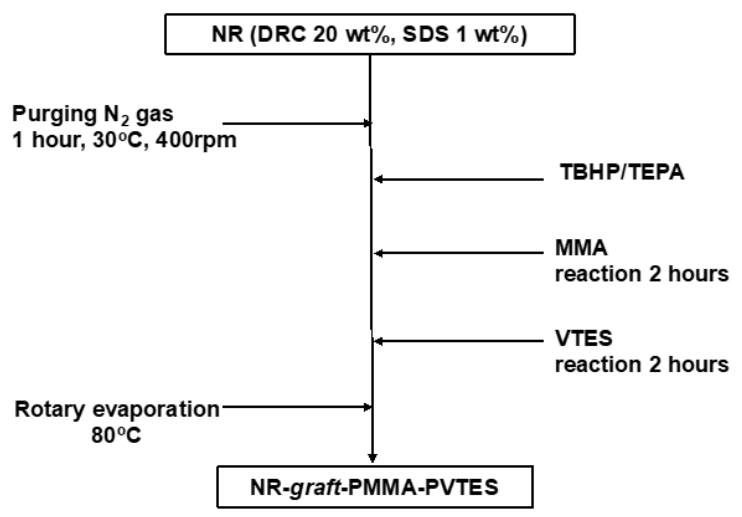

Fig. 1. Graft copolymerization of MMA and VTES onto NR

HANR latex was purified by deproteinization. HANR latex was incubated with 0.1 wt.\% urea and $1 \mathrm{wt} . \%$ SDS at room temperature for 1 hour. The dispersion was centrifuged (TOMY MX-305, Japan) at a speed of $10,000 \mathrm{rpm}$ at $15{ }^{\circ} \mathrm{C}$ for 30 minutes three times. The resulting centrifuged latexes were redispersed into 0.5 wt.\% SDS and 0.1 wt.\% SDS solution, respectively. The final DPNR will be adjusted to DRC of $20 \mathrm{wt} . \%$ and added SDS up to $1 \mathrm{wt} . \%$

The DPNR latex was purged with $\mathrm{N}_{2}$ gas for 1 hour at $30^{\circ} \mathrm{C}$, then subsequently adding TBHP/TEPA initiator at a concentration of $0.066 \mathrm{~mol} / \mathrm{kg}$ rubber. MMA monomer was dropped slowly, and the reaction was allowed to proceed at $30^{\circ} \mathrm{C}$ under continuously stirring. After 2 hours of the reaction, VTES monomer was dropped, and the reaction was continued for another 2 hours at the same condition. The reacted latex was evaporated to remove un-react monomers and initiators at $80{ }^{\circ} \mathrm{C}$ under reduced pressure for 40 minutes. The final product, NR-graft-PMMAPVTES, was cast on a petri dish and dried in a heating oven at $50{ }^{\circ} \mathrm{C}$ for 3 days and in a vacuum oven $\left(50^{\circ} \mathrm{C}\right)$ for several days. The NR-graft-PMMA-PVTES was further purified by Soxhlet extraction with a mixture of acetone:2-butanone $(3: 1 \mathrm{v} / \mathrm{v})$ under nitrogen gas for 24 hours to remove homopolymer PMMA.

\subsection{Characterizations}

Silica content was determined by burning method as described in our previous work [10]. The VTES was calculated from silica content by this equation:

$\operatorname{VTES}$ conversion $(\%)=\frac{\text { silica content } \times \text { weight of dried rubber }}{\text { weight of VTES fed }} \times \frac{190}{60}$

where 190 and $60 \mathrm{~g} / \mathrm{mol}$ are molecular weight of VTES and $\mathrm{SiO}_{2}$, respectively.

FTIR measurement is performed in a JASCO FT-IR 4600 spectrometer. The very thin film was prepared by casting latex on a petri-dish and dried for 3 days. Then it was placed on a $\mathrm{KBr}$ plate, and the measurement is set for 64 scans, ranging from $400 \mathrm{~cm}^{-1}$ to $4000 \mathrm{~cm}^{-1}$ at a resolution of $4 \mathrm{~cm}^{-1}$.

The sample was dissolved in chloroform-d, and ${ }^{1} \mathrm{H}-\mathrm{NMR}$ measurement was performed. ${ }^{13} \mathrm{C}-\mathrm{NMR}$ solid-state NMR was performed with CP/MAS probe at a spinning rate of $6 \mathrm{KHz}$. The measurements were performed in a JEOL NMR $400 \mathrm{MHz}$ (Japan).

Tensile strength of samples was measured with a Tokyo Instron 5300 according to JIS K6251 using samples cut by a dumbbell-shaped No.7. The thickness of samples was about $1 \mathrm{~mm}$ was stretch under a crosshead speed of $200 \mathrm{~mm} / \mathrm{min}$ until the sample breaks. Each sample was measured in triplicate.

\section{Results and Discussion}

\subsection{FTIR Analysis}

Fig. 2 presents FTIR spectra of NR, PMMA, and NR-graft-PMMA-PVTES. As for NR, the adsorption 
peak at $1660 \mathrm{~cm}^{-1}$ was assigned to vibration mode of $\mathrm{C}=\mathrm{C}$ bond of cis-1,4-isoprene units. For Nrgraft-PMMA-PVTES, the strong absorption peak at $1730 \mathrm{~cm}^{-1}$ was ascribed for $\mathrm{C}=\mathrm{O}$ bond of MMA unit in PMMA homopolymer, which is distinguished with the signal at $1743 \mathrm{~cm}^{-1}$ from $\mathrm{C}=\mathrm{O}$ linkage of the fatty acid ester of NR. The adsorption peak at a wavenumber of $1000-1100 \mathrm{~cm}^{-1}$ in the FTIR spectrum of NR-graftPMMA-PVTES was due to the Si-O linkages and Si$\mathrm{O}-\mathrm{Si}$ linkages. The presence of these characteristic absorption modes of $\mathrm{C}=\mathrm{O}$ and $\mathrm{Si}-\mathrm{O}$ bonds in NR-graftPMMA-PVTES, indicating that PMMA and PVTES were successfully formed. The small absorption peak at $1600 \mathrm{~cm}^{-1}$ was assigned to the absorption peak of the $\mathrm{C}=\mathrm{C}$ bond from the unreacted vinyl group of VTES. It implied that VTES was not fully polymerized.

\subsection{Calibration Curve to Determine MMA Conversion and Grafting Efficiency}

In this work, we proposed an analytical method to determine the degree of MMA conversion and grafting efficiency using FTIR spectroscopy. Six PMMA and isoprene (IR) mixtures with MMA concentrations from 0.25 to $2.0 \mathrm{mmol} / \mathrm{kg}$ rubber were prepared, and six IR spectra were measured and presented in Fig. 3.

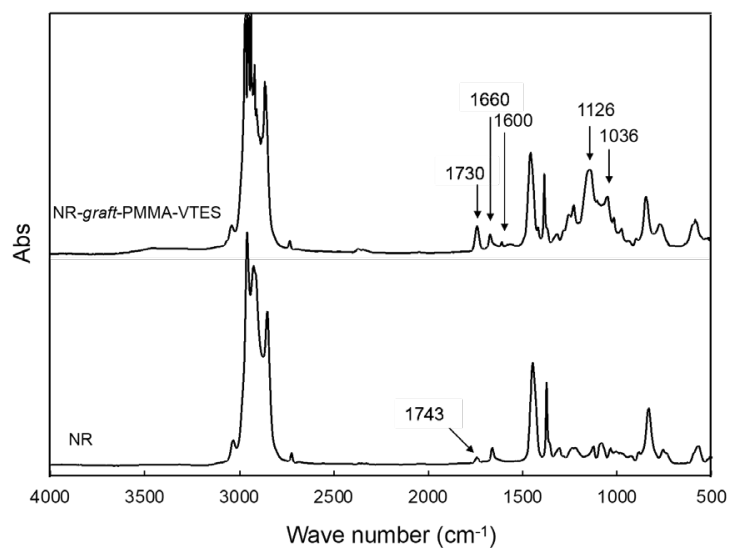

Fig. 2. FTIR spectra of NR and NR-graft-PMMAPVTES

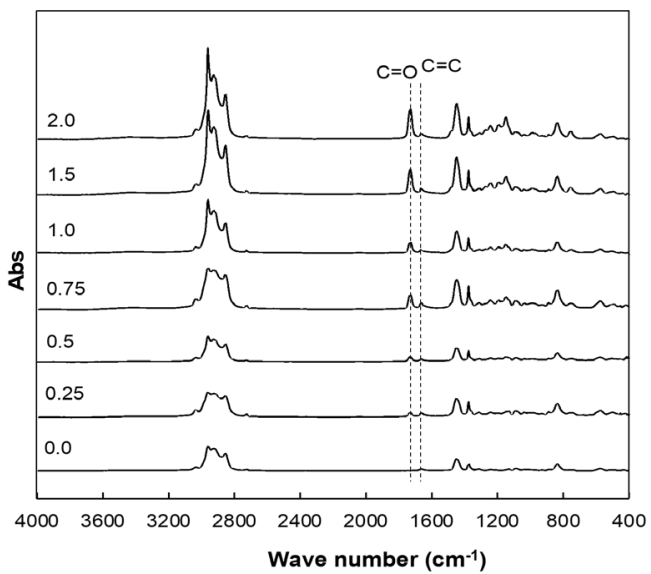

Fig. 3. FTIR spectrum of various IR/PMMA mixtures and the calibration curve
Table 1. MMA conversion and MMA grafting efficiency

\begin{tabular}{|c|c|c|}
\hline $\begin{array}{c}\text { MMA-VTES } \\
\text { concentration } \\
\text { (mol/kg-rubber) }\end{array}$ & $\begin{array}{c}\text { MMA } \\
\text { conversion } \\
(\%)\end{array}$ & $\begin{array}{c}\text { MMA grafting } \\
\text { efficency (\%) }\end{array}$ \\
\hline $0.5-1.0$ & 89.81 & 72.55 \\
\hline $0.5-1.5$ & 98.41 & 64.40 \\
\hline $1.0-1.0$ & 99.21 & 25.18 \\
\hline $1.0-1.5$ & 96.80 & 12.36 \\
\hline
\end{tabular}

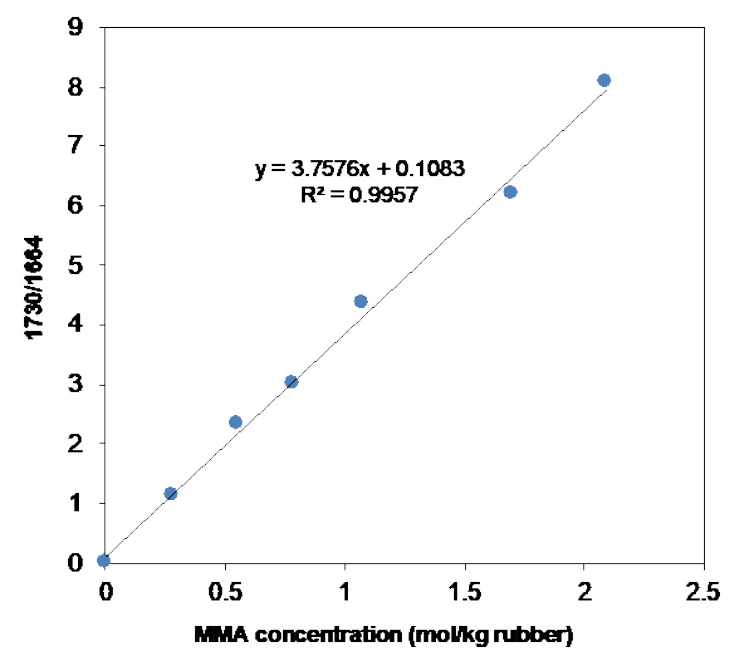

Fig. 4. Calibration curve for determination of MMA content

As can be seen, the intensity of adsorption peak at $1730 \mathrm{~cm}^{-1}$ corresponds to the amount of MMA concentration. Thus, the PMMA content can be calculated from the intensity ratio between absorption peaks at $1730 \mathrm{~cm}^{-1}$ and $1664 \mathrm{~cm}^{-1}$. Fig. 4 shows the calibration curve for the semi-quantitative analysis of MMA content. The calibration was made with the value of $\mathrm{R}^{2}$ was 0.9957 . This result demonstrated that the linearity of the calibration was acceptable to use for semi-quantitative analysis of MMA present in graft copolymer.

\subsection{Conversion and Grafting Efficiency of $M M A$}

The MMA conversion and MMA grafting efficiency were shown in Table 1. It was suggested that the high MMA conversion is obtained, more than $90 \%$. However, the grafting efficiency of MMA decreased when increasing MMA concentration. It could be explained that due to the competitiveness of VTES during graft copolymerization of MMA. The radical may transfer from PMMA to VTES and lower the grafting efficiency of PMMA to NR molecules.

\subsection{Silica Content and VTES Conversion}

Table 2 shows the silica content and VTES concentration of the graft copolymerization. The 
VTES conversion of graft copolymers increased as VTES concentration increased. However, the VTES conversion was almost similar, which was about more than $80 \%$. The VTES conversion was probably not affected by the presence of PMMA.

Table 2. Silica content and VTES conversion

\begin{tabular}{|c|c|c|}
\hline $\begin{array}{c}\text { MMA-VTES } \\
\text { concentration }\end{array}$ & $\begin{array}{c}\text { Silica } \\
\text { content } \\
(\mathrm{phr})\end{array}$ & $\begin{array}{c}\text { VTES } \\
\text { conversion } \\
(\%)\end{array}$ \\
\hline $0.5-1.0$ & 5.61 & 88.58 \\
\hline $0.5-1.5$ & 7.35 & 82.22 \\
\hline $1.0-1.0$ & 5.14 & 81.16 \\
\hline $1.0-1.5$ & 7.93 & 88.70 \\
\hline
\end{tabular}

\subsection{NMR Spectroscopy}

Fig. 5 presents ${ }^{1} \mathrm{H}-\mathrm{NMR}$ spectra for NR and NRgraft-PMMA-PVTES after acetone extraction. For $\mathrm{NR}$, there are three characteristic signals appeared at $1.67 \mathrm{ppm}\left(-\mathrm{CH}_{3}\right), 2.04\left(-\mathrm{CH}_{2}-\right)$, and $5.12 \mathrm{ppm}(-\mathrm{CH}=)$ from cis-1,4-isoprene. In the expanded spectrum of NR-graft-PMMA-PVTES, there were new signals appeared in ${ }^{1} \mathrm{H}-\mathrm{NMR}$ of NR-graft-PMMA-PVTES. The signal at $3.59 \mathrm{ppm}$ was assigned to methyl proton in the ester group of MMA. The quartet signal at $3.69 \mathrm{ppm}$ was assigned to methylene proton $\left(-\mathrm{O}-\mathrm{CH}_{2}-\right.$ $\mathrm{CH}_{3}$ ) of the ethoxy group in VTES. It suggested that there are unreacted ethoxy group existed in graft copolymer. The appearance of these signals confirmed the formation of PMMA and PVTES in graft copolymer.

Due to the formation of PVTES producing colloidal silica particles, the solubility of the graft copolymer in organic solvent decreased. In order to precisely analyze the structure of graft copolymers, it was necessary to perform NMR measurement in solidstate. Fig. 6 shows the ${ }^{13} \mathrm{C}$-NMR solid-state spectra for NR and NR-graft-PMMA-PVTES. In both spectra, five characteristic signals appeared at 24, 27, 32, 125, and $135 \mathrm{ppm}$ were assigned to the carbon atoms in cis1,4-isoprene units of NR. A new signal that appeared at $130 \mathrm{ppm}$ in ${ }^{13} \mathrm{C}$-NMR spectrum of NR-graftPMMA-PVTES was assigned to a carbon atom $(=\mathrm{CH}-)$ of vinyl groups in VTES [12]. The chemical shift for another carbon atom of the vinyl group $\left(=\mathrm{CH}_{2}\right)$ was reported to be $135 \mathrm{ppm}$, which may be overlapped with C-2 of cis-1,4-isoprene unit. The new signals at $16,45,52$, and $174 \mathrm{ppm}$ were assigned to $\underline{\mathrm{CH}}_{3}, \quad-\underline{\mathrm{CH}_{2}}-\underline{\mathrm{C}}\left(\mathrm{COOCH}_{3}\right)\left(\mathrm{CH}_{3}\right), \quad-\mathrm{COOCH}_{3}$, and $\mathrm{COOCH}_{3}$ from PMMA.
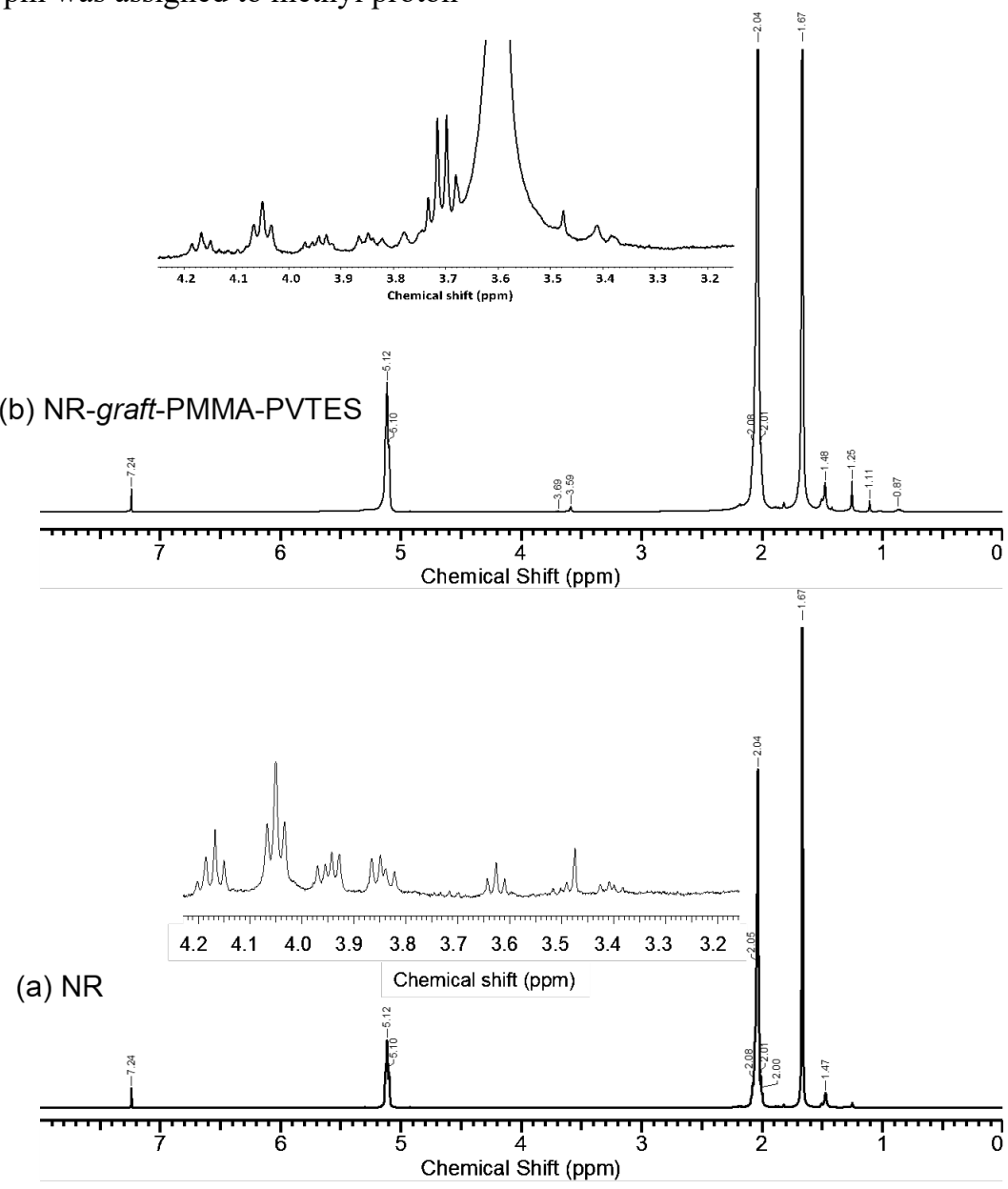

Fig. 5. ${ }^{1} \mathrm{H}-\mathrm{NMR}$ spectra of NR and NR-graft-PMMA-PVTES with solution probe 

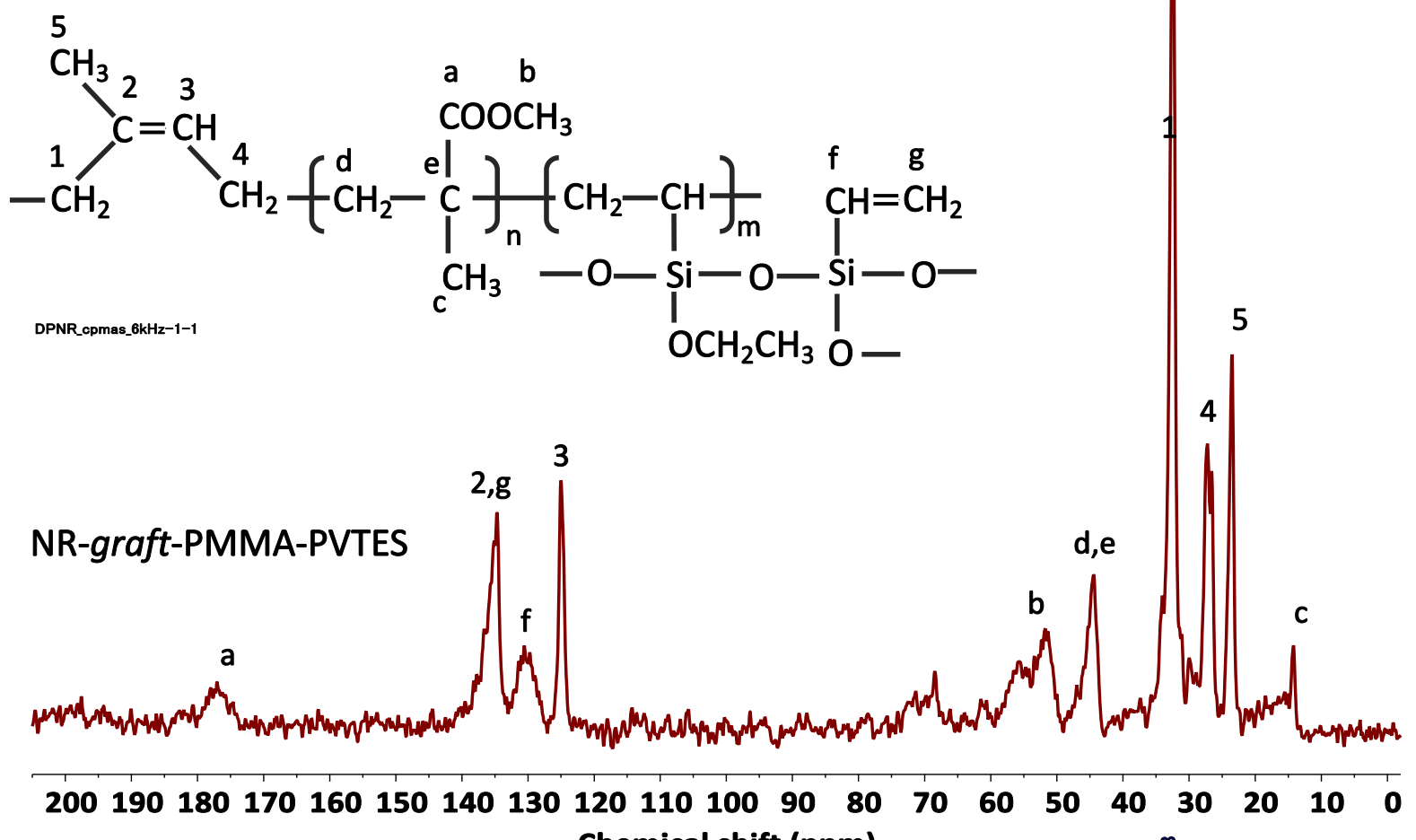
Chemical shift (ppm)

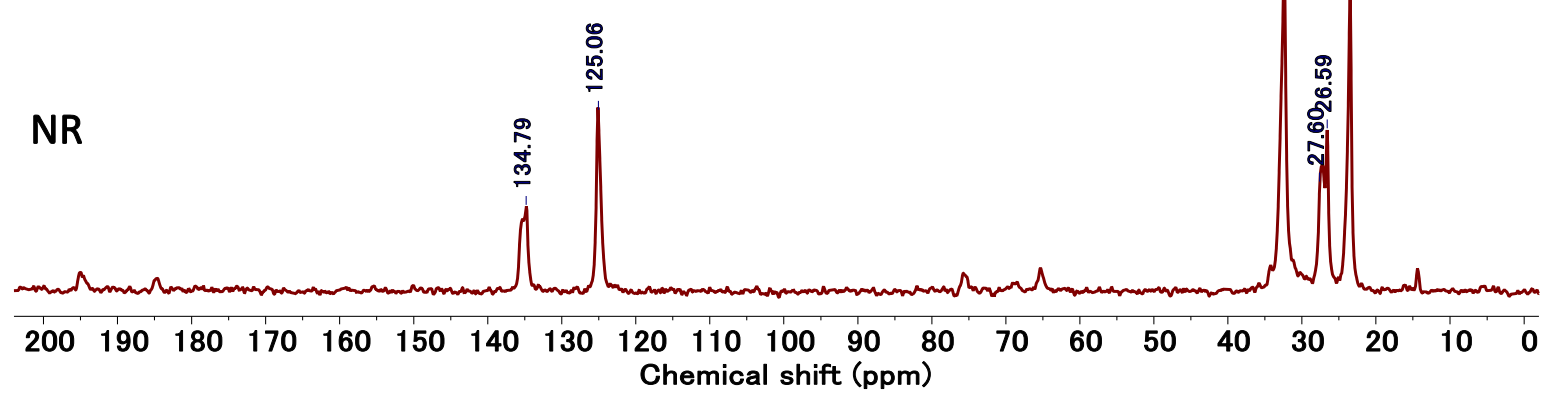

Fig. $6 .{ }^{13} \mathrm{C}-\mathrm{NMR}$ spectra of NR and NR-graft-PMMA-PVTES with CP/MAS solid probe
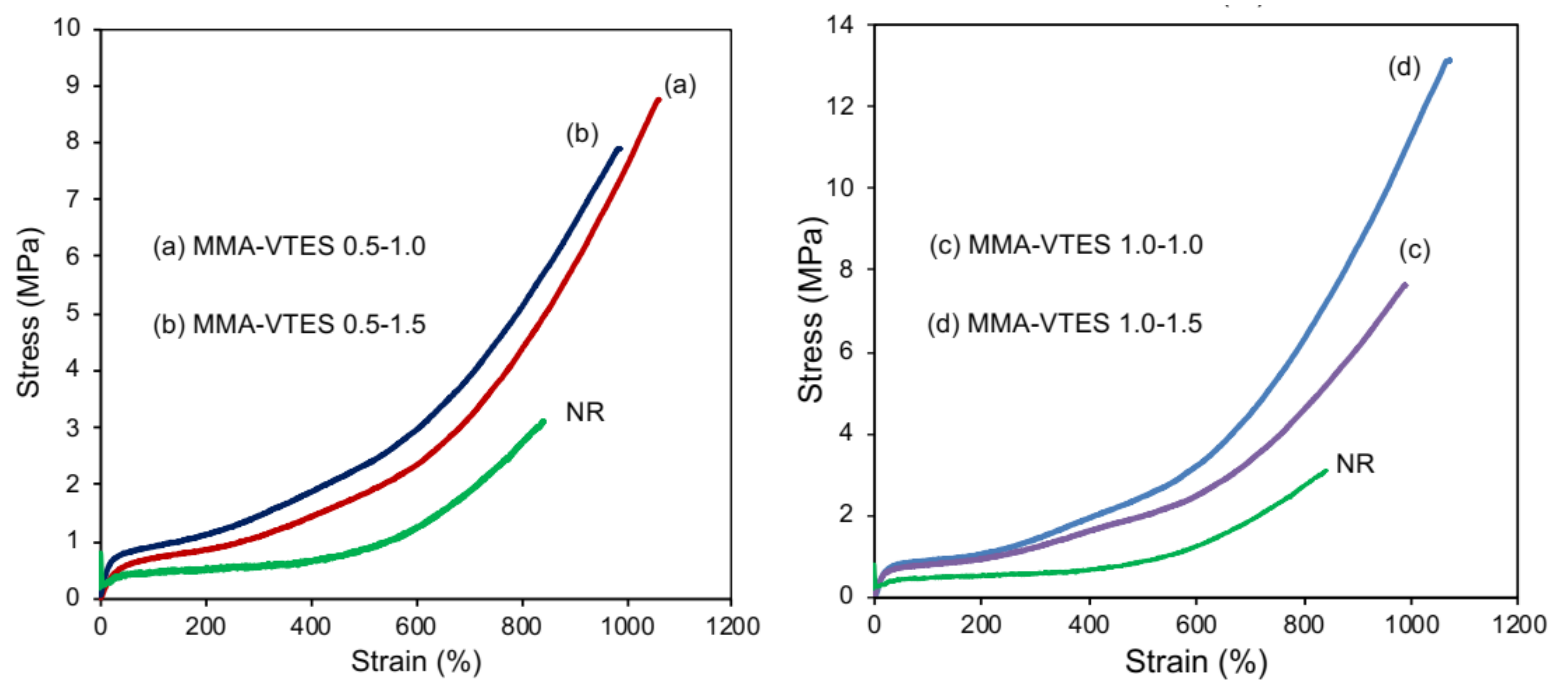

Fig. 7. Stress-strain curves for NR-graft-PMMA-PVTES at various monomer concentrations 


\subsection{Mechanical Property}

Fig. 7 shows the stress-strain curves for NRgraft-PMMA-PVTES prepared at various MMAVTES concentrations. As we can see, the stress at break of graft copolymers was about 2 - 4 times higher than that of NR. The stress of graft copolymers, as well as stress at break, increased as VTES concentration increased. It noted that the graft copolymer prepared at MMA-VTES concentration of 1.0 - 1.5 has the best tensile at break. This sample has low grafting efficiency of PMMA, which was $12.36 \%$; however, its silica content was the highest, i.e., $7.93 \mathrm{phr}$. It suggested that silica content was a more prominent factor influencing the mechanical properties of the graft copolymer.

\section{Conclusion}

Graft copolymerization of methylmethacrylate and vinytriethoxysilane was successfully performed in this work. The structure of graft copolymer was analyzed by FTIR and NMR spectroscopy confirmed the formation of grafted PMMA, and PVTES onto NR. The formation of colloidal silica due to polymerization of PVTES was also verified. The presence of VTES decreased the grafting efficiency of MMA; however, the presence of PMMA did not affect the VTES conversion. The tensile property of graft copolymers was improved compared to that of NR. The improvement of mechanical property of NR after graft copolymerization with methyl methacrylate and vinyltriethoxysilane was due to the reinforcement of colloidal silica particles generated from sol-gel reaction of VTES in the latex stage. The presence of grafted PMMA may play a role as cross-linking junctions between colloidal silica and NR.

\section{References}

[1] A. Kato, Y. Ikeda, S. Kohjiya, Carbon black-filled natural rubber composites: physical chemistry and reinforcing mechanism, In Polymer Composites, Wiley Online Library, Mar. 2012, ch. 7. https://doi.org/10.1002/9783527645213.ch17

[2] L. Xia, J. Song, H. Wang, and Z. Kan, Silica nanoparticles reinforced natural rubber latex composites: The effects of silica dimension and polydispersity on performance. J. Appl Polym Sci, 136, (2019) 47449. https://doi.org/10.1002/app.47449

[3] RO. Medupin, OK. Abubakre, AS. Abdulkareem, RA. Muriana, AS. Abdulrahaman, Carbon nanotube reinforced natural rubber nanocomposite for anthropomorphic prosthetic foot purpose. Sci Rep, 9, (2019) 20146.

https://doi.org/10.1038/s41598-019-56778-0

[4] KS. Jayaraj, S. Walpalage, SM. Egodage, Review on development of natural rubber/nanoclay nanocomposites, Proc. In Moratuwa Engineering Research Conference (MERCon), Moratuwa, pp. 1823,2015 https://doi.org/10.1109/MERCon.2015.7112313

[5] G. Asangi, S. Masao, S. Kawahara, Highly enhanced mechanical properties in natural rubber prepared with a nanodiamond nanomatrix structure. Polymer 126, 40-47, 2017

https://doi.org/10.1016/j.polymer.2017.08.025

[6] L. Fukuhara, N. Kado, NT. Thuong, S.Loykulant, K. Suchiva, K. Kosugi, Y. Yamamoto, H. Ishii, S. Kawahara, Nano matrix structure formed by graft copolymerization of styrene onto fresh natural rubber. Rubber Chemistry and Technology, 88, 117-124,2015 https://doi.org/10.5254/rct.14.85992

[7] NH. Yusof, S. Kawahara, M. Said, Modification of deproteinized natural rubber by graftcopolymerization of methyl methacrylate. J Rubb Res 11:97-110, 2008

[8] NT. Thuong, NPD. Linh, PT. Nghia, NH. Yusof, S. Kawahara, Formation of an in situ nanosilica nanomatrix via graft copolymerization of vinyltriethoxysilane onto natural rubber. Polym Adv Technol, 31, 482- 491, 2019 https://doi.org/10.1002/pat.4785

[9] T. Mircea, Free-radical copolymerization of methyl methacrylate with styrene in the presence of 2mercaptoethanol II. influence of methyl methacrylate/styrene ratio. European Polymer Journal $38,841-846,2002$ https://doi.org/10.1016/S0014-3057(01)00251-8

[10] NT. Thuong, NPD. Linh, PT. Nghia, NH. Yusof, S. Kawahara, Formation of an in situ nanosilica nanomatrix via graft copolymerization of vinyltriethoxysilane onto natural rubber, Polym Adv. Technol, 31, 482- 491, 2020 https://doi.org/10.1002/pat.4785

[11] NT. Thuong, TA. Dung, NH. Yusof, S. Kawahara Controlling the size of silica nanoparticles in filler nanomatrix structure of natural rubber, Polymer, 195, 122444, 2020 https://doi.org/10.1016/j.polymer.2020.122444

[12] AM. Zaper, JL. Koenig, Application of solid state carbon-13 NMR spectroscopy to chemically modified surfaces, Polymer Composite, 6, 156-161, (1985) https://doi.org/10.1002/pc.750060305 